\title{
Temporal evolution of bushmeat traded in High Niger National Park, Guinea, West Africa
}

\author{
Lucie Duonamou, Alexandre Konate, Jiliang Xu and Tatyana Humle
}

\begin{abstract}
The High Niger National Park is one of the most important protected areas for biodiversity conservation in Guinea. This study examined the temporal evolution of the bushmeat trade in three rural markets in the Park and in the nearest urban centre, Faranah. We collected data in markets during August-November 2017 in three villages around the Mafou core area of the Park and in Faranah, and compared these data with equivalent published data from the same rural areas in 2001 and 2011 and from Faranah in 1994, 1995, 1996 and 2011. Across all study periods, mammals predominated in the bushmeat trade. In rural markets we noted a marked increase in the number of carcasses and biomass offered for sale from 2001 onwards, whereas in Faranah there were no differences over time other than a peak in 1996. Overall, there was an increase in the sale of smaller sized species $(<10 \mathrm{~kg})$, and a marked increase in the sale of species that forage on crops, including the green monkey Chlorocebus sabaeus and warthog Phacochoerus africanus, in spite of religious taboos against the consumption of primates and Suidae. Green monkeys were not sold in markets during the 1990 os but were the dominant species in Faranah in 2011 and 2017. Our findings suggest a marked shift in traded species, associated with crop protection by farmers and economic incentives to kill and trade crop-foraging species. This study highlights the value of a longitudinal perspective for investigating the dynamic relationship between local livelihoods and biodiversity conservation.
\end{abstract}

Keywords Bushmeat trade, crop-protection, Guinea, High Niger National Park, human-wildlife conflict, hunting, market surveys, primate conservation

Supplementary material for this article is available at doi.org/10.1017/So030605319001443

\footnotetext{
Lucie Duonamou ([D orcid.org/0000-0002-6912-5923) School of Nature Conservation, Beijing Forestry University, Beijing, China

Alexandre Konate (D orcid.org/0000-0003-4896-8929) Institute Superior of Agronomy and Veterinary of Faranah, Faranah, Guinea

JILIANG XU (Corresponding author, (D) orcid.org/0000-0002-2542-6441) School of Nature Conservation, Beijing Forestry University, Beijing 100083, 35 Qinghua East Road, Haidian District, China. E-mail xujiliang@bjfu.edu.cn

Tatyana Humle (Corresponding author, (D) orcid.org/0000-0002-1919-631X) Durrell Institute of Conservation and Ecology School of Anthropology and Conservation, Marlowe Building, University of Kent, Canterbury CT2 7NR, UK E-mail t.humle@kent.ac.uk

Received 2 May 2019. Revision requested 9 September 2019.

Accepted 13 December 2019. First published online 18 September 2020.
}

\section{Introduction}

T unting, which was once considered a subsistence and 1 traditional activity supplying protein resources for rural populations in West Africa, has become an important commercial activity (Bowen-Jones, 2003). Bushmeat hunting is pervasive across West Africa and is one of the main threats to mammal populations in the region (Fa et al., 2002, 2003; Lindsey et al., 2011; Humle \& Konate, 2015; Ripple et al., 2016). Unsustainable hunting practices are affecting c. $68 \%$ of wildlife species in West and Central Africa, and are directly affecting c. 84 mammalian species (Bowen-Jones, 2003). Depletion of wildlife is increasingly affecting people's wellbeing and access to sources of protein and revenue, especially in rural areas (Nasi et al., 2011). To date most bushmeat studies have been carried out in forested areas (van Velden et al., 2018); few have focused on savannah-dominated ecosystems in West Africa, especially within Guinea's dry forest systems (Lindsey et al., 2013). It is critical to gather knowledge from such landscapes, to better understand the impact of hunting on wildlife and wildlife depletion on ecosystem integrity, as well as on people's livelihoods and well-being in less forested and more arid regions of sub-Saharan Africa.

Studies in Africa generally suggest that urban demand is a major driver of the bushmeat trade (Brashares et al., 2011; Fa et al., 2015). However, other factors such as poverty and human population growth also influence this trade (Lindsey et al., 2011; Pimm et al., 2014; Ripple et al., 2016). Farmers in many regions also practice lethal wildlife control using snares and, increasingly, shotguns, to protect their crops, although it remains unclear to what extent such mitigation strategies fuel the bushmeat trade (Alexander et al., 2015; Humle \& Konate, 2015). Such practices often target rodent, primate and Suidae species, which are amongst the most common crop-foraging species in Africa (Brooks et al., 1993; McNamara et al., 2015; Garriga et al., 2018). In West Africa, primates account for $1-50 \%$ of carcasses recorded in bushmeat markets (Davies \& Brown, 2008). Wildlife authorities in Uganda have declared baboons Papio sp., the vervet monkey Chlorocebus pygerythrus and red river hog Potamochoerus porcus to be vermin and farmers can therefore hunt these species to reduce damages and losses to their crops (Naughton-Treves et al., 1998). Bushmeat consumption studies in Lalehum near the Gola North Forest Reserve in Sierra Leone showed that the greater cane rat Thryonomys swinderianus was more frequently killed and consumed during the so-called hungry season, when rice is growing, whereas duikers were hunted and consumed more during the dry season (Davies \& Brown, 2008). Although 
hunting is an important source of income for many rural populations in Africa (Wilkie et al., 2005), some species are buffered from such practices as they are not hunted because of their cultural value, or because of religious beliefs (Reuter et al., 2016; MacCarthy, 2018). For example, in the 1990 os in Lalehum in Sierra Leone, the western chimpanzee Pan troglodytes verus was the species most commonly cited as taboo to eat and was not hunted for meat (Davies \& Brown, 2008).

High Niger National Park is one of the last remaining dry forest-savannah mosaics in West Africa, and is a priority site for the conservation of ungulates and the western chimpanzee (Fleury-Brugière \& Brugière, 2001; Kormos et al., 2003). In Guinea, subsistence hunting of wildlife requires a permit and so, in theory, offtake could be regulated and sustainable (Saïdou \& Djellouli, 2011). Nevertheless, many protected areas across West and Central Africa, including in Guinea, are affected by human activities such as hunting, agriculture and mining, and these activities remain poorly regulated (Brugière \& Magassouba, 2009). National statistics on the bushmeat trade are not available for Guinea, but local-scale studies have indicated that bushmeat is the main source of animal protein for rural people, as in many other African countries (Humle \& Konate, 2015). Commercial hunting for bushmeat is a serious threat to animal species across many protected areas as a result of a lack of law enforcement and unsustainable hunting practices. The failure to comply with hunting periods recommended by law and poor respect for the prohibition of hunting in strictly protected core areas therefore threaten the sustainability of wildlife resources (Dia, 2005).

There were studies of bushmeat use in the Park during 1994-1996 (Ziegler, 1996) and in 2001 (Fleury-Brugière \& Brugière, 2010). Both these studies focused on market surveys, revealing that the Park harbours a diverse mammalian fauna that is threatened by hunting, but did not seek to understand the drivers of the bushmeat trade or resource utilization. The existing regulations for the control of bushmeat trade in this area remain poorly enforced and protection efforts are inconsistent across the Park (L. Duonamou \& A. Konate, pers. obs., 2017). Here we explore how the bushmeat trade has evolved since these earlier studies, using data gathered in 2011 (Humle \& Konate, 2015) and 2017. We focus on the species hunted, the number of carcasses recorded, biomass harvested, and the body size of hunted species and whether they are cropforagers. We aim to provide critical information for the overdue update of the Park's management plan (2006-2010) and help to understand local drivers of the bushmeat trade and to alleviate current pressures on wildlife within the Park.

\section{Study area}

The $12,470 \mathrm{~km}^{2}$ High Niger National Park lies in the northeast Republic of Guinea across the Prefectures of Kankan,
Kouroussa, Dabola and Faranah (Brugière et al., 2005). Circa 80,000 people live around the Park, with 44,407 of these in the Mafou area near the urban centre of Faranah, dominated by Malinke people, who are Muslim (Brugière et al., 2005). Islam as practised in the region traditionally prohibits the consumption of Suidae and primate species (Mbotiji, 2002). Mean annual rainfall is $1,200-1,700 \mathrm{~mm}$ and mean monthly temperature $17-25^{\circ} \mathrm{C}$, with a maximum of $35^{\circ} \mathrm{C}$ at the end of the dry season in April-May (Fleury-Brugière \& Brugière, 2001; Ziegler et al., 2002). Agricultural activities in the region are concentrated within the Park's buffer zones. Rice, maize, peanuts and cassava are the dominant crops and most people are engaged in farming. The Park has two core areas, where human settlement or activity are strictly prohibited, and two buffer zones (c. $8,500 \mathrm{~km}^{2}$ ) that vary in the degree to which local people are permitted to harvest and utilize resources. The two strictly protected core areas are Mafou $\left(554 \mathrm{~km}^{2}\right)$ and Kouya $\left(675 \mathrm{~km}^{2}\right)$, separated by $60 \mathrm{~km}$ (Brugière et al., 2005). We focused our study on the Mafou sector, which has benefitted from most protection efforts since 2013 . A collaboration between the Chimpanzee Conservation Center, the Park authorities and the United Nations Office for Project Services has facilitated the deployment of trained ecoguards in and around the Mafou core area (Fig. 1). The Park harbours c. 50\% of all known mammal species in Guinea (Ziegler et al., 2002; Brugière \& Magassouba, 2003), including the Vulnerable lion Panthera leo and Critically Endangered western chimpanzee (Kamyk, 2017; Humle et al., 2018).

\section{Methods}

Data on bushmeat hunting were collected during AugustNovember 2017 in three rural villages (Sidakoro, Mansiramoribaya and Koumandi Koura) in the Mafou sector of the Park and in the urban centre of Faranah. The three villages each have a small market in which bushmeat is sold. Data collection was based on market surveys, for comparison and consistency with previous studies (Ziegler, 1996; Brugière \& Magassouba, 2009). For each bushmeat item, we counted the number of carcasses and identified the species. For estimating biomass, we used the mean body weight of each species (Kingdon, 2015). This was also used to categorize species by weight $(<10,10-50$ and $>50 \mathrm{~kg})$. Based on local knowledge, species were categorized as non-pest (not reported to forage on crops), pest (forages on crops) or carnivore (reported to depredate livestock; Supplementary Table 3).

To evaluate the temporal evolution of the bushmeat trade, we compared our data with those collected in previous studies. For the rural area, we compared our data to those of Humle \& Konate (2015), gathered in 2011, and Brugière \& Magassouba (2009), collected in 2001 across 


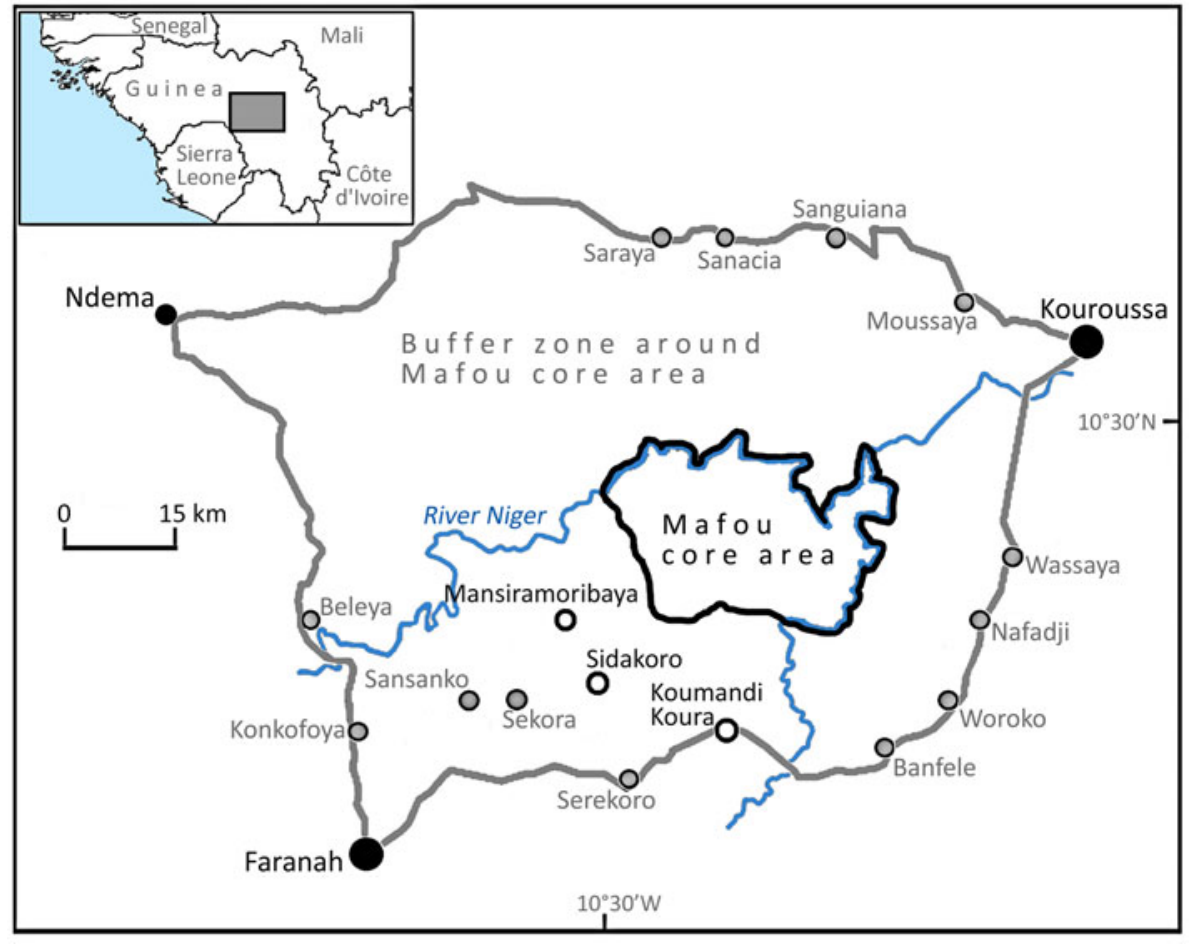

FIG. 1 The Mafou area of High Niger National Park indicating the location of the main urban centre, Faranah, and villages located within the Park, including the study villages Mansiramoribaya, Sidakoro and Koumandi Koura (adapted from Brugière \& Magassouba, 2009). the same three villages and during the same months (August-November). Our data from the urban centre of Faranah were compared to those of Humle \& Konate (2015), collected in 2011, and Ziegler (1996), collected in 1994, 1995 and 1996, during the same months (SeptemberNovember).

All statistical analyses were performed SPSS 20.0 (IBM Corp., Armonk, USA). We used a one-way ANOVA followed by a least significance difference post hoc test to assess differences in mean monthly number of carcasses recorded and biomass of hunted species in urban and rural areas across years. A $\chi^{2}$ test was used to explore associations between frequencies of carcasses by weight and wildlife categories across years. For $\chi^{2}$ tests with more than a $2 \times 2$ contingency design, $z$-scores based on the adjusted standardized residuals were used to assess the cells' contribution to any significant results, with values $>|1.96|$ indicating significance at $\mathrm{P}<0.05$. Statistical significance for all other inferential statistics was at $\mathrm{P}<0.05$.

\section{Results}

The market surveys revealed that birds, mammals and reptiles were traded. We recorded a total of 1,162 carcasses of 42 wild animal species in 21 families, corresponding to $21,314 \mathrm{~kg}$ of biomass in the three villages and Faranah (Supplementary Tables $1 \& 2$ ). Taxa of eight families were recorded in both urban and rural areas (Bovidae, Hystricidae, Canidae, Cercopithecidae, Nesomyidae, Thryonomyidae,
Suidae, Numididae), and Bovidae, Hystricidae, Cercopithecidae, Thryonomyidae and Suidae were the most commonly recorded taxa in both areas. The Suidae included two species: the red river hog Potamochoerus porcus and the warthog Phacochoerus africanus. The consumption of Suidae is prohibited by Islam and, although the red river hog was already hunted and traded in 1994-1996, the presence of the warthog in the markets was first recorded in 2011, and in rural areas the number of carcasses doubled from 2011 to 2017 (Supplementary Table 2).

For Faranah, there was a significant difference in the mean monthly number of carcasses recorded across years (oneway ANOVA $F(4,10)=3.308, \mathrm{P}=0.039)$, and the least significant difference post hoc test showed that the mean monthly number of carcasses recorded in 1996 was significantly greater than in 1994, 2011 and 2017, but not than in 1995 (Fig. 2a). For the three villages, the mean monthly number of carcasses in 2017 was significantly greater than in 2001 and 2011 (oneway ANOVA $F(2,9)=6.847, \mathrm{P}=0.016$ ) but there were no significant differences between 2001 and 2011 (Fig. 2b). The monthly mean biomass exhibited the same patterns and statistical differences across study periods in Faranah (except that a significantly greater biomass was recorded in both 1995 and 1996 than in other years) and the villages (oneway ANOVA, Faranah: $F(4,10)=6.327, \mathrm{P}=0.008$; one-way ANOVA, villages: $F(2,9)=5.192, \mathrm{P}=0.032$; Fig. 3).

Overall, seven species were the most traded, comprising $>10 \%$ of all carcasses recorded in both rural or urban settings. Six of these species were traded in both urban and rural areas: the greater cane rat, red-flanked duiker Cephalophus 
(a) Urban

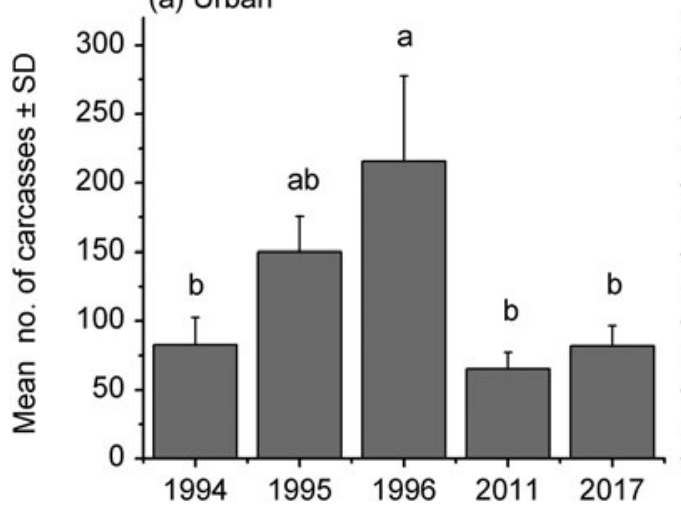

(b) Rural

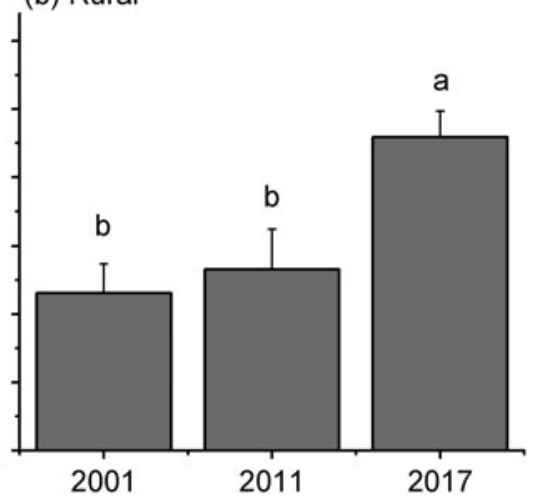

FIG. 2 Monthly mean number of carcasses recorded in (a) urban and (b) rural areas (Fig. 1) over 5 and 3 years, respectively. Bars marked with the same letter are not significantly different $(\mathrm{P}>0.05)$.

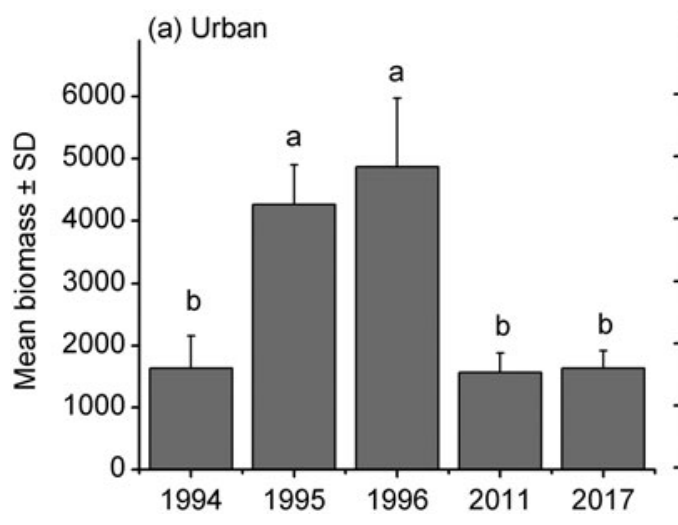

(b) Rural
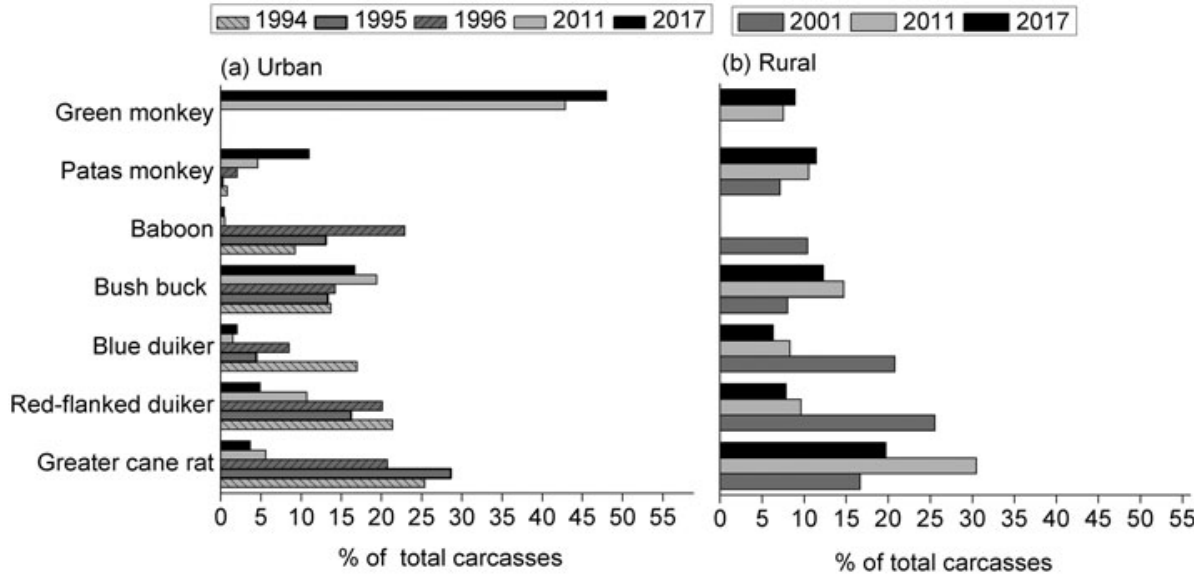

FIG. 4 The most common species (as per cent of total carcasses) recorded in (a) urban and (b) rural markets (Fig. 1) over 5 and 3 years, respectively.

FIG. 3 Monthly mean biomass of carcasses recorded in (a) urban and (b) rural markets (Fig. 1) over 5 and 3 years, respectively. Bars marked with the same letter are not significantly different $(\mathrm{P}>0.05)$.

rufilatus, blue duiker Cephalophus maxwelli, bushbuck Tragelaphus scriptus, baboon Papio sp. and green monkey Chlorocebus sabaeus (Fig. 4). The patas monkey Erythrocebus patas never exceeded $10 \%$ of all carcasses recorded in rural areas, but comprised $11 \%$ of all carcasses recorded in Faranah in 2017. The green monkey was never reported in Faranah during 1994-1996, but it was the most abundant species in 2011 and 2017. Although its presence in rural markets was not as prominent, its relative abundance increased there from 2001 to 2017.
The occurrence of the baboon decreased markedly in Faranah after 1996 (Fig. 4a), and was only recorded in rural markets in 2001. In Faranah (Fig. 4a), the greater cane rat and the redflanked duiker were the most abundant species in 1994 and 1995, whereas the green monkey was the most abundant species in 2011 and 2017. In the rural areas (Fig. 4b), the redflanked and blue duikers were the most abundant species in 2001 but the greater cane rat and the bushbuck were the most abundant in 2011 and 2017. 
$\square<10 \mathrm{~kg} \square 10-50 \mathrm{~kg} \square>50 \mathrm{~kg}$

(a) Uban

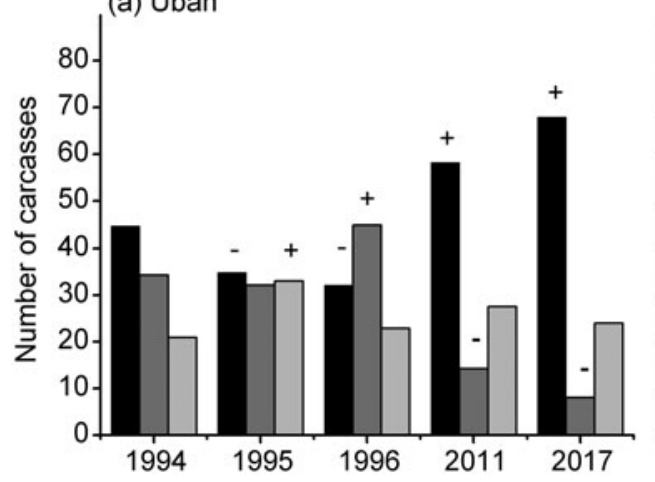

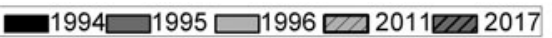

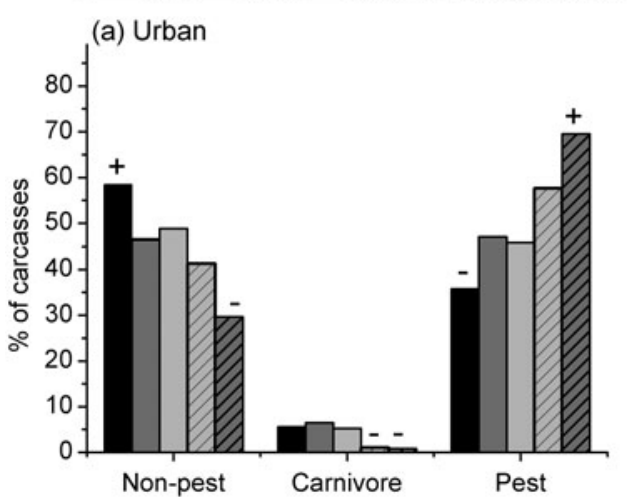

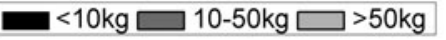

(b) Rural

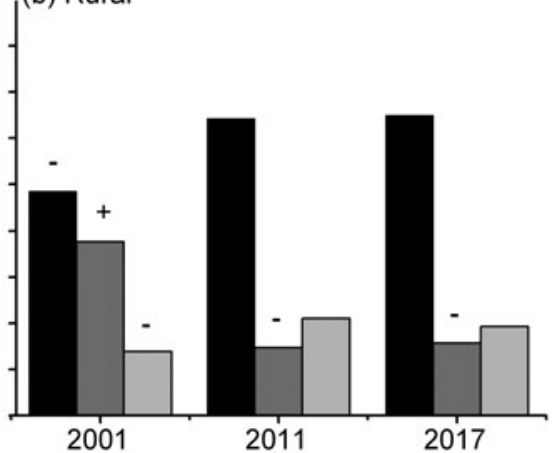

FIG. 5 Number of carcasses by species weight category in (a) urban and (b) rural markets (Fig. 1) over 5 and 3 years, respectively. The signs indicate where the observed frequency is significantly more $(+)$ or less (-) than the expected frequency, based on standardized residuals and $z$-score values.
The number of carcasses in each species weight category varied significantly between study years in both $\mathrm{Fa}$ ranah $\left(\chi^{2}(8)=183.833 ; \mathrm{P}<0.001\right)$ and the three villages $\left(\chi^{2}(4)=107.093\right.$; $<<0.001$; Fig. 5). Although all weight categories of species were traded as expected in 1994 in Faranah, in 1995 fewer species $<10 \mathrm{~kg}$ and more species $>50 \mathrm{~kg}$ were traded than expected. In 1996 similarly significantly fewer species $<10 \mathrm{~kg}$ and more species weighing $10-50 \mathrm{~kg}$ were traded than expected (Fig. 5a). In 2011 and 2017, however, there was a shift, with significantly more species $<10 \mathrm{~kg}$, fewer species weighing $10-50 \mathrm{~kg}$, and species $>50 \mathrm{~kg}$ traded as expected (Fig. 5a). In rural areas in 2001 species $<10 \mathrm{~kg}$ and $>50 \mathrm{~kg}$ were traded less than expected, and species weighing $10-50 \mathrm{~kg}$ were traded significantly more than expected (Fig. 5b). In 2011 and 2017 small and large species were traded as expected and medium sized species were traded significantly less than expected (Fig. 5b). However, overall, the majority of species were small in 2011 and 2017 in both Faranah and the villages (Fig. 5).

There was a significant association in the frequency of carcasses recorded across years and wildlife categories (non-pest, pest and carnivore) in Faranah $\left(\chi^{2}(8)=76.68\right.$, $\mathrm{P}<0.001)$ and the rural areas $\left(\chi^{2}(4)=43.388, \mathrm{P}<0.001\right)$. In Faranah, the carcasses of non-pest species were traded significantly more than expected in 1994 but significantly less in 2017. The carcasses of pest species comprised $69.5 \%$ of all species sold in Faranah in 2017, significantly more than expected (Fig. 6a). Carnivore species were traded in Faranah as expected in 1994, 1995 and 1996 but significantly less than expected in 2011 and 2017 (Fig. 6a). In rural areas, non-pest species were traded significantly more than expected in 2001, and pest species significantly less. However, in 2011 pest species were traded significantly more than expected in villages, and there was no significant difference between observed and expected values in 2017, although these species comprised $52.1 \%$ of all recorded carcasses in 2017 (Fig. 6b). No significant differences were noted for carnivore species in rural areas.

\section{Discussion}

Our findings reveal that mammalian species comprise the greatest proportion of wildlife traded in the study region, corroborating studies carried out elsewhere in West and Central Africa ( $\mathrm{Fa}$ et al., 2006). In the urban centre of Faranah, the number of carcasses and offtake of biomass were similar in 1994 and 2017, despite peaks in 1995 and 
1996. However, bushmeat trade in the three rural areas increased from 2001 to 2017 whether based on carcass numbers or biomass. This finding is at odds with previous studies indicating that bushmeat demand is driven by increased demand from urban markets (Fa et al., 2002). T. Humle \& F. St John (unpubl. data) uncovered evidence that many urban residents in Faranah preferred meat of domestic animals to bushmeat. However, demand from other urban centres in the forest region of Guinea and the role of intermediaries connecting villages with urban traders further afield may still be important drivers of the bushmeat trade and wider regional and transborder trade patterns; such influences need to be better understood. The absence of an increase in the bushmeat trade in Faranah since 1996 could potentially reflect a depletion of wildlife species, although sales in the villages increased between 2001 and 2017. This could also indicate that recent law enforcement initiatives, with road blocks at critical exit points from the Park, are successfully discouraging transport of bushmeat to the city. However, the increase in the bushmeat trade in rural areas could also be linked to an increase in the human population combined with limited access to alternative sources of protein such as beef and chicken, which are seldom sold in villages (T. Humle \& F. St John, unpubl. data).

Although we noted a decrease in carnivore and non-pest species being hunted over time, our findings indicated a significant increase in the trading of species that forage on crops, in both rural and urban areas. Crop-damaging species are increasingly being traded in bushmeat markets across rural West Africa (e.g. in Ghana: Alexander et al., 2015). Farmers also use such bushmeat to pay off loans and/or secure additional income for agricultural activities, including the purchase of herbicides and fertilizers, which are now widely used locally (A. Konate, pers. obs., 2011). The majority of hunters in the three study villages practice farming, and social science surveys have indicated that farm protection is a prime driver for hunting (L. Duonamou et al., unpubl. data). Primate species, such as baboons, green and patas monkeys, and Suidae species, are often cited as being the most common crop-foraging species in rural areas (L. Duonamou et al., unpubl. data). Our findings revealed a general increase in the diversity of primate species hunted, with the exception of the chimpanzee, which was only recorded once, in 2001, and a substantial intensification in the sale of green monkeys in the urban centre of Faranah. Our market surveys also indicated a marked increase in the sale of red river hogs and warthogs, especially in villages, since 2001. Even if some people in Faranah consume monkey and wild pig meat, sale and consumption are more common and widespread in south-eastern Guinea where people are predominantly animists; Faranah and surrounding villages have become a source of supply of these species for this region of Guinea (T. Humle, pers. obs., 2011). However, such hunting practices are evidently challenging religious taboos against the consumption of these taxa. Traditionally, a religious taboo prohibiting the consumption of Suidae species amongst Muslims in the region mainly focused on the warthog rather the red river hog. These species are, however, increasingly been killed to protect crops and, whereas in the past the meat was either donated to non-Muslims or given to dogs, farmers now gain economically from their sale, providing an additional incentive for killing (L. Duonamou et al., unpubl. data). Warthog meat in particular is also now been termed the 'meat of the youth' in rural areas, where the younger Muslim generation is discreetly preparing and consuming this meat (L. Duanomou \& A. Konate, pers. obs., 2017). In addition, primate meat is also often supplied to local restaurants in Faranah, where people tend not to question the type of meat that is being served and where taboos are not respected as fully as in the household (A. Konate, unpubl. data).

Our findings also indicated a significant shift in the dominant species for sale in 2017 compared with earlier years. Although the red-flanked and blue duikers were amongst the most traded species during 1994-2001 in both rural and urban areas, they were markedly less evident in 2011 and 2017. In addition, although the cane rat remained the most abundantly traded species in rural areas, its trade decreased markedly in 2011 and 2017 in the urban centre of Faranah. This shift may be related to increased demand in rural areas for the greater cane rat, the meat of which is highly appreciated and readily available (A. Konate \& L. Duonamou, pers. obs., 2017), and a shift in consumption of bushmeat species such as primates, warthog and red river hog, which are not traditionally consumed in villages, and hence preferentially transported to and traded in urban areas. The decline in duiker species may indicate these species have declined as a result of unsustainable hunting. In 2001 and 2017, these species were replaced by the green monkey in the urban centre and by species such as the Gambian pouched rat Cricetomys gambianus in the rural areas (Supplementary Table 3). The bushbuck was the only species whose relative abundance remained relatively consistent across years in both urban and rural settings, suggesting that the population of this species has remained stable despite hunting.

Although large-bodied species such as the bushbuck were relatively constant in their presence in the markets across years, our study revealed a significant shift in more recent years from medium-sized species towards small species $(<10 \mathrm{~kg})$ in both rural and urban settings. Market surveys in some West African countries have similarly revealed a marked shift towards smaller species such as rodents, generally reflecting a depletion in larger mammals linked to unsustainable levels of hunting (Cowlishaw et al., 2005).

Our study highlights temporal changes in bushmeat available for sale across rural and urban settings, sheds light on the dynamics of the bushmeat trade in and around 
the Mafou area of the High Niger National Park, and provides some insights into the drivers of this trade. We focused, however, on only one area of the Park and it remains unclear whether the patterns we observed are the same in other prefectures, such as Kouroussa. Nevertheless, our findings suggest that, contrary to patterns noted elsewhere, especially in Central Africa, urban demand does not appear to be driving the bushmeat trade in this region, especially as supply in rural areas has increased steadily, whereas trade in the local urban center of Faranah remained the same as it was in 1994. Our findings also suggest that agricultural expansion, crop protection practices and the economic status of farmers require greater consideration when addressing the bushmeat trade in and around the High Niger National Park. In addition, there appears to be an erosion in religious taboos regarding the killing and consumption of primates and Suidae species. This shift is accentuated by a demand for these species from other regions of the country and crop protection challenges faced by farmers locally, combined with the financial benefits resulting from the sale of crop-foraging species. Despite the local reduction in urban demand for bushmeat, pressures on wildlife in the Park are evident and it is hence critical to develop a social science-based approach to better understand the relative importance of various drivers of hunting, to address unsustainable hunting practices and to ensure an improved balance between conservation and people's livelihoods.

Acknowledgements We are grateful to the Ministry of the Environment, the Guinean Office for Protected Areas, especially Colonel Keita, and Captain Kouyaté, director of the High Niger National Park in Guinea, for granting us permission to pursue this research, the field assistants who helped with data collection, and all the people who facilitated our research. This work was funded by an Arcus Foundation grant to TH (No. G-PGM-1702-2116) and the National Sciences Foundations of China.

Author contributions Conception and design of research: LD, AK, $\mathrm{TH}$; fieldwork and market survey: LD, AK; statistical analysis and writing: $\mathrm{LD}, \mathrm{AK}, \mathrm{TH}$; revision: $\mathrm{LD}, \mathrm{AK}, \mathrm{JX}, \mathrm{TH}$.

\section{Conflicts of interest None.}

Ethical standards This research abided by the Oryx guidelines on ethical standards, followed the standards of the Social Research Association, and was reviewed and approved by the ethics' committee of the School of Anthropology and Conservation of the University of Kent, UK. The Ministry of the Environment, the Guinean Office for Protected Areas, and the High Niger National Park authorities in Guinea granted permission to pursue this research, which complied with all legal requirements for research within the country. Lucie Duonamou, a Guinean PhD student, coordinated and conducted the data collection in collaboration with a Guinean researcher, Alexandre Konate. All field assistants received appropriate training. All market stall sellers were told of the study's objectives and their participation and collaboration were secured on a voluntary and anonymous basis prior to commencing data collection and to ensure that the study would not have any direct or indirect impact on trade.

\section{References}

Alexander, J.S., McNamara, J., Rowcliffe, J.M., Oppong, J. \& Milner-Gulland, E.J. (2015) The role of bushmeat in a West African agricultural landscape. Oryx, 49, 643-651.

Bowen-Jones, E. (2003) Bushmeat: traditional regulation or adaptation to market forces. In Trade in Wildlife: Regulation for Conservation (ed. S. Oldfield), pp. 132-145. Earthscan, London, UK.

Brashares, J.S., Golden, C.D., Weinbaum, K.Z., Barrett, C.B. \& OKELLO, G.V. (2011) Economic and geographic drivers of wildlife consumption in rural Africa. Proceedings of the National Academy of Sciences of the United States of America, 108, 13931-13936.

Brooks, J.E., Bruggers, R.L. \& Harris, M.A. (1993) Vertebrate Damage Control Research in Agriculture, Fiscal Years 1992 and 1993. Agency for International Development, Washington, DC, USA.

Brugière, D. \& Magassouba, B. (2003) Mammalian diversity in the National Park of Upper Niger, Republic of Guinea-an update. Oryx, 37, 19-19.

Brugière, D. \& Magassouba, B. (2009) Pattern and sustainability of the bushmeat trade in the Haut Niger National Park, Republic of Guinea. African Journal of Ecology, 47, 630-639.

Brugière, D., Dia, M., Diakité, S., Gbansara, M., Mamy, M., Saliou, B. \& Magassouba, B. (2005) Large-and medium-sized ungulates in the Haut Niger National Park, Republic of Guinea: population changes 1997-2002. Oryx, 39, 50-55.

Cowlishaw, G., Mendelson, S. \& Rowcliffe, J.M. (2005) Evidence for post-depletion sustainability in a mature bushmeat market. Journal of Applied Ecology, 42, 460-468.

Davies, G. \& Brown, D. (2008) Bushmeat and Livelihoods: Wildlife Management and Poverty Reduction. John Wiley \& Sons, Hoboken, USA.

DiA, M. (2005) Evaluation de la Problématique de la Viande de Brousse en Guinée. Food and Agriculture Organization of the United Nations, Rome, Italy. fao.org/tempref/docrep/fao/o1o/ai57of/ ai57ofoo.pdf [accessed 30 November 2018].

FA, J.E., Peres, C.A. \& Meeuwig, J. (2002) Bushmeat exploitation in tropical forests: an intercontinental comparison. Conservation Biology, 16, 232-237.

FA, J.E., Currie, D. \& Meeuwig, J. (2003) Bushmeat and food security in the Congo Basin: linkages between wildlife and people's future. Environmental Conservation, 30, 71-78.

Fa, J.E., Seymour, S., Dupain, J., Amin, R., Albrechtsen, L. \& Macdonald, D. (2006) Getting to grips with the magnitude of exploitation: bushmeat in the Cross-Sanaga rivers region, Nigeria and Cameroon. Biological Conservation, 129, 497-510.

Fa, J.E., Olivero, J., Farfán, M.Á., Márquez, A.L., Duarte, J., NACKoney, J. et al. (2015) Correlates of bushmeat in markets and depletion of wildlife. Conservation Biology, 29, 805-815.

Fleury-Brugière, M.-C. \& Brugière, D. (2001) Estimation Préliminaire de la Population de Chimpanzés de la Zone Intégralement Protegée-Mafou du Parc National du Haut Niger, République de Guinée. Rapport de Projet de la Composante Parc National du Haut Niger du Programme pour l'Appui à la Gestion Intégrée des Ressources, Guinée.

Fleury-Brugière, M.-C. \& Brugière, D. (2010) High population density of Pan troglodytes verus in the Haut Niger National Park, Republic of Guinea: implications for local and regional conservation. International Journal of Primatology, 31, 383-392.

Garriga, R.M., Marco, I., Casas-Diaz, E., Amarasekaran, B. \& Humle, T. (2018) Perceptions of challenges to subsistence agriculture, and crop foraging by wildlife and chimpanzees Pan troglodytes verus in unprotected areas in Sierra Leone. Oryx, 52, 761-774. 
Humle, T. \& Konate, A. (2015) Primates and bushmeat hunting around the High Niger National Park, Guinea, West Africa: drivers and patterns of change. Folia Primatologica, 86, 298-298.

Humle, T., Maisels, F., Oates, J., Plumptre, A. \& Williamson, E. (2018) Pan troglodytes (errata version published in 2016). In The IUCN Red List of Threatened Species 2016: e.T15933A102326672. dx.doi.org/10.2305/IUCN.UK.2016-2.RLTS.T15933A17964454.en [accessed 7 January 2020].

KАМ К, C.M. (2017) Boldness and natural behaviors in the African lion (Panthera leo): how are they related? BSc thesis. University of New Hampshire, Durham, USA.

Kingdon, J. (2015) The Kingdon Field Guide to African Mammals. Bloomsbury Publishing, London, UK.

Kormos, R., Boesch, C., Bakarr, M.I. \& Butynski, T.M. (2003) West African Chimpanzees: Status Survey and Conservation Action Plan. IUCN, Gland, Switzerland.

Lindsey, P.A., Romanach, S., Tambling, C.J., Chartier, K. \& Groom, R. (2011) Ecological and financial impacts of illegal bushmeat trade in Zimbabwe. Oryx, 45, 96-111.

Lindsey, P.A., Balme, G., Becker, M., Begg, C., Bento, C., Bocchino, C. et al. (2013) The bushmeat trade in African savannas: impacts, drivers, and possible solutions. Biological Conservation, $160,80-96$.

MacCarthy, J. (2018) Effects of hunting and human disturbance on wildlife near villages in northeastern Gabon. MSc thesis. Duke University, Durham, USA.

Мвотілг, J. (2002) Sustainable use of wildlife resources: the bushmeat crisis. In Wildlife Management Workshop Paper. Food and Agriculture Organization of the United Nations, Rome, Italy.

McNamara, J., Kusimi, J.M., Rowcliffe, J.M., Cowlishaw, G., Brenyah, A. \& Milner-Gulland, E.J. (2015) Long-term spatio-temporal changes in a West African bushmeat trade system. Conservation Biology, 29, 1446-1457.
Nasi, R., Taber, A. \& van Vliet, N. (2011) Empty forests, empty stomachs? Bushmeat and livelihoods in the Congo and Amazon Basins. International Forestry Review, 13, 355-368.

Naughton-Treves, L., Treves, A., Chapman, C. \& Wrangham, R. (1998) Temporal patterns of crop-raiding by primates: linking food availability in croplands and adjacent forest. Journal of Applied Ecology, 35, 596-606.

Pimm, S.L., Jenkins, C.N., A bell, R., Brooks, T.M., Gitt leman, J.L., Joppa, L.N. et al. (2014) The biodiversity of species and their rates of extinction, distribution, and protection. Science, 344,1246752 .

Reuter, K.E., Randell, H., Wills, A.R. \& Sewall, B.J. (2016) The consumption of wild meat in Madagascar: drivers, popularity and food security. Environmental Conservation, 43, 273-283.

Ripple, W.J., Abernethy, K., Betts, M.G., Chapron, G., Dirzo, R., Galetti, M. et al. (2016) Bushmeat hunting and extinction risk to the world's mammals. Royal Society Open Science, 3, 160498.

SaÏDou, D. \& Djellouli, Y. (2011) La gestion dérogatoire: une stratégie associant péniblement l'État et les communautés locales dans le Parc National du Haut Niger (Guinée). [VertigO] La Revue Électronique en Sciences de l'Environnement, 11, 10763.

van Velden, J., Wilson, K. \& Biggs, D. (2018) The evidence for the bushmeat crisis in African savannas: a systematic quantitative literature review. Biological Conservation, 221, 345-356.

Wilkie, D.S., Starkey, M., A bernethy, K., Effa, E.N., Telfer, P. \& Godoy, R. (2005) Role of prices and wealth in consumer demand for bushmeat in Gabon, Central Africa. Conservation Biology, 19, 268-274.

Ziegler, S. (1996) An initial study of hunting in the Upper Niger National Park. Nature et Faune (FAO/PNUE), 12, 13-29.

Ziegler, S., Nikolaus, G. \& Hutterer, R. (2002) High mammalian diversity in the newly established National Park of Upper Niger, Republic of Guinea. Oryx, 36, 73-8o. 